Article

\title{
Evaluation of Composted Organic Wastes and Farmyard Manure for Improving Fertility of Poor Sandy Soils in Arid Regions
}

\author{
Houda Oueriemmi ${ }^{1,2}$, Petra Susan Kidd ${ }^{3,+}$, Carmen Trasar-Cepeda ${ }^{3} \mathbb{D}$, Beatriz Rodríguez-Garrido ${ }^{3}$,

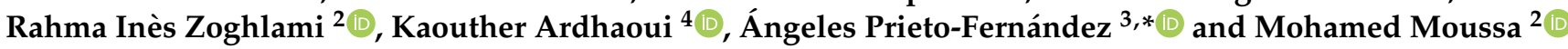 \\ 1 Higher Institute of Water Sciences and Techniques, University of Gabes, 6072 Gabes, Tunisia; \\ houdaoueriemmi@outlook.com \\ 2 Laboratory of Eremology and Combating Desertification (LR16IRA01), Arid Regions Institute, \\ University of Gabes, 4119 Medenine, Tunisia; inesrahma.zoghlami@gmail.com (R.I.Z.); \\ mohamed.moussa@ira.rnrt.tn (M.M.) \\ 3 Department of Soil Biochemistry, IIAG-CSIC, Av. de Vigo s/n, Campus Vida, \\ E-15705 Santiago de Compostela, Spain; ctrasar@iiag.csic.es (C.T.-C.); beatriz@iiag.csic.es (B.R.-G.) \\ 4 Higher Institute of Applied Biology, University of Gabes, 4119 Medenine, Tunisia; \\ ardhaouikaouther@gmail.com \\ * Correspondence: apf@iiag.csic.es \\ + Deceased.
}

Citation: Oueriemmi, H.; Kidd, P.S.; Trasar-Cepeda, C.; Rodríguez-Garrido, B.; Zoghlami, R.I.; Ardhaoui, K.; Prieto-Fernández, Á.; Moussa, M. Evaluation of Composted Organic Wastes and Farmyard Manure for Improving Fertility of Poor Sandy Soils in Arid Regions. Agriculture 2021, 11, 415. https://doi.org/ 10.3390/agriculture11050415

Academic Editors: Pavel Krasilnikov, Miguel A. Taboada and Amanullah

Received: 10 April 2021

Accepted: 30 April 2021

Published: 4 May 2021

Publisher's Note: MDPI stays neutral with regard to jurisdictional claims in published maps and institutional affiliations.

Copyright: (c) 2021 by the authors. Licensee MDPI, Basel, Switzerland. This article is an open access article distributed under the terms and conditions of the Creative Commons Attribution (CC BY) license (https:// creativecommons.org/licenses/by/ $4.0 /)$

\begin{abstract}
Farmyard manure, an amendment traditionally used for improving the fertility of sandy soils in arid climates, is becoming scarce and expensive. Its shortage makes it necessary to evaluate, at field scale, the suitability and medium-term performance of other cheap, highly available substitutes. A field trial was established to analyze the effects of a single application of three organic residues on barley yield and nutrient uptake and selected soil properties after two consecutive harvests. Municipal solid waste compost (MSWC), sewage sludge compost (SSC) and farmyard manure (FYM) were tested at rates of $0,20,40$ and $60 \mathrm{tha}^{-1}$. Adding all three organic amendments increased organic matter, cation exchange capacity and available $\mathrm{P}, \mathrm{Ca}, \mathrm{Mg}$ and $\mathrm{K}$ in the soil, the grain yield (up to 51\%), and the barley plants' nutrient contents. After the second harvest, a positive residual effect of the amendment was observed in plant yield (up to 77\%) and nutrient contents. MSWC and SSC induced slight increases on the extractable fractions (BCR protocol) of $\mathrm{Co}, \mathrm{Cu}$ and $\mathrm{Ni}$, relative to the unamended soil. The results demonstrate the positive immediate and residual effect of the amendments evaluated as fertilizers for agricultural purposes.
\end{abstract}

Keywords: organic amendments; fertility; trace elements; plant nutrients

\section{Introduction}

Agricultural soils in arid regions in southern Tunisia are often skeletal, have very low organic matter contents $(<1 \%)$ and are poor in nutrients, such as nitrogen $(\mathrm{N})$, potassium (K) and phosphorus (P) [1]. Arid soils typically also have a sandy texture, a poor soil structure and low water holding capacity [2]. These arid zones are, therefore, unfavorable and inhospitable for plant growth and development.

Inorganic fertilizers are conventionally used to improve soil fertility and plant production. Chemical fertilizers provide nutrients in forms that are readily available to crops, thus rapidly enhancing crop growth and yields. However, as these fertilizers do not increase the soil organic matter content, they do not greatly improve many of the soil properties essential for ensuring soil health [2]. In addition, mineral fertilizers tend to leach below the root zone as a result of the input of irrigation water or rainwater, which can lead to more serious problems, such as surface and groundwater contamination [3], soil acidification or alkalinisation, decreased levels of beneficial microbial communities and increased sensitivity to harmful pests [4]. 
The use of organic amendments is known to improve the physical, chemical and microbiological properties of soil, thus positively affecting soil fertility and increasing crop yields $[5,6]$. In Tunisia, farm manure is traditionally used to improve soil fertility and increase soil organic matter content and associated properties (structure, water holding capacity, nutrient storage and cycling, soil microbial activity, etc.) [7]. However, this type of organic amendment is becoming expensive and is often nutrient-deficient [7]. At the same time, the rapid urbanization and booming economy of the country have led to the generation of huge quantities of organic waste. Using organic waste (which includes municipal solid waste compost and sewage sludge compost) as fertilizer is becoming increasingly widespread and is a potentially valuable method of recycling and a promising alternative to disposing of the waste by landfill or incineration [8]. Composting contributes to reducing the amount of urban residues, thus making their management less difficult [9], and it constitutes an efficient, cost-effective and environmentally safe biological process for transforming solid waste into valuable soil amendments [9]. Municipal solid waste compost and sewage sludge compost have been used to amend agricultural soils for many years in different parts of the world. Both types of waste can improve soil fertility due to their high nutrient and organic matter contents [10].

Amending agricultural soils with composted organic residues has been shown to improve water penetration, hydraulic conductivity, water retention and aggregate stability [11]. Increases in the cation exchange capacity (CEC) and buffering capacity of soil have also been observed and attributed to the abundant humic substances present in these types of compost [12]. The addition of organic wastes to soils also promotes the growth of microorganisms, which stimulates soil respiration and nutrient cycling and the synthesis of various phytohormones and low molecular mass compounds and enzymes that benefit plant growth $[13,14]$. Many studies have shown that the addition of compost has positive effects on vegetation, including increased plant biomass and crop yields [15]. The use of compost can promote photosynthesis and increase the chlorophyll content of forage plants [13]. However, undesirable changes can also occur in agricultural soils after the addition of composts or biosolids, depending on the origin, rate and frequency of addition and soil type [10]. Among the potential risks, trace elements in this type of material can lead to contamination of soil and water and can have adverse effects on crop growth and soil microorganisms $[16,17]$.

It is now accepted that the total element concentrations in soils amended with wastebased composts do not provide reliable information about the availability and toxicity of trace elements because of the various, complex patterns of distribution of these elements in different chemical species or solid phases [18]. Element uptake by plants depends on the soil's bioavailability in the soil and particularly on the supply from more plant-available fractions. Only the dissolved and exchangeable fractions of trace elements can be absorbed and utilized by plants [19]. For this reason, assessment of the mobility and availability of trace elements in the soil must take into account the distribution of the elements in the various constitutive soil fractions [20]. The sequential extraction techniques provide important information on the fraction that is potentially available to plants [21].

Composted organic wastes have been widely used for both agricultural and environmental restoration purposes $[2,8,22,23]$. The properties of this type of residues make them particularly suitable for improving fertility and restoring low organic matter soils in arid and semiarid areas [2,22]. To date, most field studies using these amendments for agricultural purposes have been carried out in the most urbanized and industrialized countries, in many cases in temperate regions [8]. In Tunisia, the arid and semiarid soils are generally well characterized [24], and several studies have been conducted to evaluate the impact of the repetitive application of manure and municipal solid waste compost to soils developed in a semiarid climate. These studies focused on the effects on soil microbial biomass [25], crop yields [26] and the distribution of trace metals in soil $[9,16]$ and in different plant parts [27]. However, in the arid regions in Tunisia, little is known about how applying sewage sludge or municipal solid waste composts affects the trace element availability in 
soils or about the lasting effects of the initial application on successive crops. Furthermore, the efficacy of these urban and industrial residues relative to traditional farm manure has not been investigated in detail. The information obtained is essential for designing a sustainable use of urban composted residues, alone or in combination with manures, as soil amendments in traditional agricultural systems on the $\mathrm{N}$ of Africa. Therefore, the main objectives of this study were (i) to assess and compare the immediate effects of a single application of farmyard manure and that of municipal solid waste compost or sewage sludge compost on soil physicochemical properties, the distribution of trace elements in soil, and on yield and mineral nutrition of barley grown in sandy agricultural soil in an arid climate (Tunisia) and (ii) to assess whether the effects of the addition of these composts last beyond the first harvest. We hypothesized that given the very poor conditions for plant growth in the sandy soils in the region: (1) the addition of all three organic residues will enhance soil fertility and plant productivity; (2) the input of organic matter and the more favorable conditions for microbial activity in compost- and manure-amended soils will maintain the improved soil nutrient status for longer than one year; and (3) the high $\mathrm{pH}$ will prevent the trace elements occurring in available forms and will, therefore, reduce the potentially negative effects of these elements on plants growing in compost-amended soils.

\section{Materials and Methods}

\subsection{Experimental Design}

A field-scale trial was established in 2017 at the experimental field station of the Arid Regions Institute, located in southeastern Tunisia, northeast of the city of Medenine $\left(33^{\circ} 16^{\prime} 21^{\prime \prime} \mathrm{N}, 10^{\circ} 19^{\prime} 30^{\prime \prime} \mathrm{E}\right)$. The climate is typically semiarid to arid, with a mean annual rainfall of $150 \mathrm{~mm}$ and a mean annual temperature ranging between $18{ }^{\circ} \mathrm{C}$ and $20^{\circ} \mathrm{C}$. The soil has a sandy texture and is classified as Regosols [24]. The main physicochemical properties of the soil are shown in Table 1.

Three different types of organic amendments were used in the experiment: farmyard manure (FYM), municipal solid waste compost (MSWC) and sewage sludge compost (SSC). The FYM from the excreta of sheep and straw aged for one year was produced in farm close to the city of Medenine (Tunisia). The MSWC was obtained from the pilot composting station of Beja (100 km northwest of Tunis). The urban compost was produced under aerobic conditions by mixing a separated organic fraction of household rubbish with green garden waste (tree and shrub cuttings, leaves, weeds and grass clippings) and arranging the mixture in long narrow piles (windrows). The composting process was completed in six months, as indicated by the constant $\mathrm{C} / \mathrm{N}$ ratio and temperature. The SSC was produced by mixing activated sewage sludge, collected from the wastewater treatment plant located in Medenine (southeast of Tunisia), with green garden waste under aerobic conditions. The main characteristics of farmyard manure and of the two composts used in the study are summarized in Table 1.

The field experiment was designed as a randomized complete block trial with a total of 30 plots. Each plot of surface area $1 \mathrm{~m}^{2}(1 \mathrm{~m} \times 1 \mathrm{~m})$ was separated in all directions by a buffer zone of $0.70 \mathrm{~cm}$. In total, ten treatments were tested. These included a control (CTR) treatment and three doses $\left(20,40\right.$ and $\left.60 \mathrm{tha}^{-1}\right)$ of each of the three organic amendments described above: FYM20, FYM40, FYM60, MSWC20, MSWC40, MSWC60, SSC20, SSC40 and SSC60. Manure is commonly applied at $20 \mathrm{tha}^{-1}$ to agricultural soils in the study region to compensate for the soil organic matter deficit. The $\mathrm{C}$ and $\mathrm{N}$ contents were quite similar in the SSC and FYM and much higher than in the MSWC. The highest dose $\left(60 \mathrm{tha}^{-1}\right)$ of MSWC was chosen to supply the same amounts of $C$ and $\mathrm{N}$ provided by $20 \mathrm{tha}^{-1}$ of FYM. These organic amendments were applied once at the beginning of the experiment (before sowing) and incorporated to $10-15 \mathrm{~cm}$ depth by manual hoeing. Throughout the experiment, all of the plots were regularly irrigated and manually weeded every month to prevent uptake of the soil nutrients by adventitious plants. 
Table 1. Some physicochemical characteristics of the soil and of the three types of organic amendments used (farmyard manure, FYM; sewage sludge compost, SSC, and municipal solid waste compost, MSWC).

\begin{tabular}{|c|c|c|c|c|}
\hline & Soil & FYM & SSC & MSW \\
\hline Sand $(\%)$ & $89 \pm 1$ & - & - & - \\
\hline Clay $(\%)$ & $9 \pm 0$ & - & - & - \\
\hline Silt (\%) & $2 \pm 0$ & - & - & - \\
\hline Texture & Sandy & - & - & - \\
\hline $\mathrm{pH} \mathrm{H} \mathrm{H}_{2} \mathrm{O}$ & $8.3 \pm 0.1$ & $8.7 \pm 0.0$ & $6.2 \pm 0.0$ & $7.6 \pm 0.0$ \\
\hline $\mathrm{EC}\left(\mu \mathrm{S} \mathrm{cm}^{-1}\right)$ & $525 \pm 4.6$ & $15.3 \pm 0.4$ & $15.7 \pm 0.0$ & $1.6 \pm 0.0$ \\
\hline P Olsen (mg kg $\left.{ }^{-1}\right)$ & $3.2 \pm 0.09$ & $577.7 \pm 62.4$ & $400.9 \pm 26.3$ & $181.7 \pm 8.1$ \\
\hline CEC $\left(\right.$ cmolc kg $\left.^{-1}\right)$ & $41.3 \pm 2.7$ & nd & $128.9 \pm 2.3$ & $57.6 \pm 0.9$ \\
\hline Exchangeable $\mathrm{Ca}\left(\mathrm{cmolc} \mathrm{kg}^{-1}\right)$ & $39.1 \pm 2.6$ & nd & $73.8 \pm 0.7$ & $42.6 \pm 0.8$ \\
\hline Exchangeable $\mathrm{Mg}\left(\mathrm{cmolc} \mathrm{kg}^{-1}\right)$ & $1.5 \pm 0.1$ & nd & $33.6 \pm 1.2$ & $4.9 \pm 0.0$ \\
\hline Exchangeable K (cmolc kg $\left.{ }^{-1}\right)$ & $0.5 \pm 0.0$ & nd & $17.3 \pm 0.7$ & $9.9 \pm 0.2$ \\
\hline $\mathrm{Ca} / \mathrm{Mg}$ & $26.3 \pm 0.8$ & nd & $2.2 \pm 0.1$ & $8.6 \pm 0.1$ \\
\hline$\% \mathrm{C}^{\mathrm{O}}$ & $0.21 \pm 0.0$ & $28.9 \pm 1.9$ & $22.5 \pm 1.1$ & $7.2 \pm 0.0$ \\
\hline$\% \mathrm{~N}$ & $0.03 \pm 0.0$ & $1.2 \pm 0.0$ & $1.9 \pm 0.1$ & $0.5 \pm 0.0$ \\
\hline $\mathrm{C} / \mathrm{N}$ & $7.2 \pm 0.1$ & $23.6 \pm 2.1$ & $11.8 \pm 0.1$ & $13.8 \pm 0.8$ \\
\hline \multicolumn{5}{|l|}{$\begin{array}{l}\text { Pseudo-total element concentrations } \\
\qquad \mathrm{g} \mathrm{kg}^{-1}\end{array}$} \\
\hline 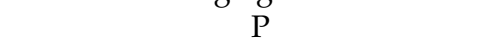 & $0.3 \pm 0.0$ & $4.0 \pm 0.1$ & $10.3 \pm 0.2$ & $4.5 \pm 0.1$ \\
\hline $\mathrm{K}$ & $2.1 \pm 0.0$ & $13.2 \pm 0.3$ & $6.2 \pm 0.2$ & $8.4 \pm 0.1$ \\
\hline $\mathrm{Al}$ & $8.2 \pm 0.2$ & $5.5 \pm 0.0$ & $6.4 \pm 0.3$ & $28.0 \pm 0.0$ \\
\hline $\mathrm{Ca}$ & $32.6 \pm 2.1$ & $28.5 \pm 0.3$ & $53.8 \pm 1.2$ & $138.8 \pm 3.3$ \\
\hline $\mathrm{Mg}$ & $2.9 \pm 0.1$ & $5.6 \pm 0.1$ & $6.7 \pm 0.2$ & $4.7 \pm 0.0$ \\
\hline \multicolumn{5}{|l|}{$\mathrm{mg} \mathrm{kg}^{-1}$} \\
\hline $\mathrm{Cu}$ & $4.4 \pm 0.4$ & $16.8 \pm 0.7$ & $97.3 \pm 2.9$ & $54.9 \pm 0.8$ \\
\hline $\mathrm{Zn}$ & $12.4 \pm 1.3$ & $87.0 \pm 5.8$ & $267.2 \pm 4.2$ & $286.1 \pm 3.2$ \\
\hline $\mathrm{Pb}$ & $3.4 \pm 0.1$ & $1.4 \pm 0.2$ & $20.4 \pm 1.4$ & $76.3 \pm 10.6$ \\
\hline $\mathrm{Cd}$ & $0.2 \pm 14.4$ & $0.2 \pm 0.0$ & $0.5 \pm 0.0$ & $0.6 \pm 0.0$ \\
\hline $\mathrm{Ni}$ & $6.0 \pm 0.5$ & $6.8 \pm 0.3$ & $15.3 \pm 0.1$ & $31.5 \pm 0.5$ \\
\hline $\mathrm{Cr}$ & $13.7 \pm 0.3$ & $10.3 \pm 0.5$ & $18.9 \pm 0.9$ & $28.5 \pm 0.3$ \\
\hline Co & $1.5 \pm 0.2$ & $1.2 \pm 0.1$ & $1.9 \pm 0.0$ & $5.1 \pm 0.4$ \\
\hline Mn & $83.4 \pm 1.9$ & $92.7 \pm 1.2$ & $95.9 \pm 2.4$ & $298.9 \pm 2.1$ \\
\hline
\end{tabular}

Maximum heavy metal contents $\left(\mathrm{mg} \mathrm{kg}^{-1}\right)$ permitted by EU legislation [28]. Class A compost: $\mathrm{Cu} 70 ; \mathrm{Zn} \mathrm{200;} \mathrm{Pb} 45 ; \mathrm{Cd} 0.7 ; \mathrm{Ni} 25 ; \mathrm{Cr} 70$. Class B compost: $\mathrm{Cu}$ 300; Zn 500; Pb 150; Cd 2; Ni 90; Cr 250. nd: not detected.

Barley (Hordeum vulgare L.) was sown once in each of the two consecutive years of the study. The barley seeds were first sown in November 2017, and the first harvest was in May 2018. Seeds were sown again in November 2018, and the second harvest was in May 2019. Seeds were sown at a density of $100 \mathrm{~kg} \mathrm{ha}^{-1}$.

Samples consisting of the entire barley plant (root, stem and grain) were collected from each replicate plot while the barley was harvested, in May 2018 and in May 2019, for subsequent analysis. In each replicate plot, soil samples were taken at $0-20 \mathrm{~cm}$ depth with a hand auger at the same time as the plants were harvested. The samples were dried in a forced-air oven at $40^{\circ} \mathrm{C}$, crushed to pass through a $2 \mathrm{~mm}$ sieve and stored in a polyethylene bag before physicochemical characterization.

\subsection{Analytical Methods}

\subsubsection{Soil Physicochemical Parameters}

Soil pH and electrical conductivity (EC) were recorded in 1:2.5 and 1:5 (w:v) soil: water suspensions. Soil texture was determined using the Robinson pipette method [29]. Total organic C (TOC) was determined by dichromate oxidation in a strongly acid medium and subsequent titration with ferrous ammonium sulfate [30]. Organic matter was calculated by multiplying the total organic carbon content by 1.724. Total nitrogen (TN) was determined by the Kjeldahl method [31]. Soils were extracted with Olsen's reagent $\left(0.5 \mathrm{M} \mathrm{NaHCO}_{3}\right.$ 
adjusted to $\mathrm{pH}$ 8.2, 1:20 soil: solution ratio), and available $\mathrm{P}$ was determined colorimetrically using the molybdenum blue method [32]. Cation exchange capacity (CEC) was estimated using $1 \mathrm{M} \mathrm{NH}_{4} \mathrm{Cl}(1: 20 \mathrm{w}: \mathrm{v})$ as the sum of exchangeable cations $\mathrm{Ca}, \mathrm{Mg}, \mathrm{Al}, \mathrm{Na}$ and $\mathrm{K}$ and measured by ICP-OES (Varian Vista-Pro, Australia). Pseudo-total metal concentrations were determined using $0.2 \mathrm{~g}$ of soil digested in a $3: 1$ mixture of concentrated $\mathrm{HNO}_{3}: \mathrm{HCl}$ to which $3 \mathrm{~mL} \mathrm{H}_{2} \mathrm{O}_{2}$ was added in Teflon PFA vessels in a laboratory microwave system (Ethos EASY; Milestone, Sorisole, Italy). The contents of $\mathrm{Cd}, \mathrm{Cu}, \mathrm{Pb}, \mathrm{Zn}, \mathrm{Ni}, \mathrm{Cr}, \mathrm{Co}, \mathrm{Mn}$ concentrations in the digestates were determined by inductively coupled plasma optical emission spectrometry (Varian Vista-Pro, Australia).

Element fractionation was carried out following a modified BCR protocol [33]. The soils were first shaken at room temperature with $1 \mathrm{M} \mathrm{NH}_{4} \mathrm{Cl}$ for $16 \mathrm{~h}$. This reagent extracts the water-soluble and exchangeable metal fraction (exchangeable fraction). The resulting residue was then shaken at room temperature with $0.11 \mathrm{M} \mathrm{CH}_{3} \mathrm{COOH}$ for $16 \mathrm{~h}$. This step extracts the carbonate-bound metal fraction. The residue was shaken for $16 \mathrm{~h}$ at room temperature with $0.10 \mathrm{M} \mathrm{NH}_{2} \mathrm{OH} \mathrm{HCl}$ adjusted to $\mathrm{pH} 2.0$ with $\mathrm{HNO}_{3}$. This fraction mainly contains iron and manganese oxide-bound metals (reducible fraction). The residue was then digested with $30 \% \mathrm{H}_{2} \mathrm{O}_{2}$, and the mixture was evaporated to dryness over a water bath at $85^{\circ} \mathrm{C}$, and the resulting extract was shaken with $1 \mathrm{M} \mathrm{NH}_{4} \mathrm{OAc}$ adjusted to $\mathrm{pH} 2.0$ with $\mathrm{CH}_{3} \mathrm{COOH}$ for $16 \mathrm{~h}$. This step extracts primarily organically bound and sulfide metals (oxidizable fraction). Finally, the residual fraction (silicate-bound metals) was digested as described above to determine pseudo-total metal concentrations. The concentrations of $\mathrm{Co}, \mathrm{Cu}$ and $\mathrm{Ni}$, were analyzed in the filtered supernatants from each extraction were determined by ICP-OES. All metal concentrations were expressed per $\mathrm{kg}$ dry weight (DW) soil.

The compost and manure were analyzed using the same methods described for soil samples [34].

\subsubsection{Plant Analysis}

At the end of the experiment, the whole barley plants were harvested. The individual plants were separated into roots, stems and grains. The roots were carefully washed with deionized water. All of the separated plant parts were dried at $70{ }^{\circ} \mathrm{C}$ for $48 \mathrm{~h}$ and ground to $<1 \mathrm{~mm}$. The total nitrogen concentration was determined by the Kjeldahl method. $\mathrm{Ca}, \mathrm{K}, \mathrm{Mg}, \mathrm{Fe}, \mathrm{Mn}, \mathrm{Cu}$ and $\mathrm{Zn}$ concentrations were determined by atomic absorption spectrophotometry (Shimadzu AA-6200, Shimadzu, Duisburg, Germany) in digestates of the plant tissues obtained after ashing subsamples of plant biomass in a muffle furnace $\left(550{ }^{\circ} \mathrm{C}, 6 \mathrm{~h}\right)$ and subsequent acid digestion with $6 \mathrm{~N} \mathrm{HCl}$ [34].

\subsection{Statistical Analysis}

Data were analyzed using IBM SPSS Statistics 25 (Model AA-6200, Shimadzu, NY, USA). For each sampling period, the effects of organic amendments on soil physicochemical properties, soil metal concentrations, plant yield and nutrient concentrations were assessed by one-way analysis of variance (ANOVA) followed by multiple comparisons of means with the post hoc Duncan test for independent means. Normality and homogeneity of variances were tested by the Kolmogorov-Smirnov and Levene's tests, respectively.

\section{Results}

\subsection{Soil Physicochemical Properties}

The soil used in the study was sandy soil ( $90 \%$ of sand), with very low organic matter and nutrient content, low $\mathrm{C} / \mathrm{N}$ ratio and alkaline $\mathrm{pH}$ (pH in water, 8.3) (Table 1). In general, none of the three organic amendments induced important changes in soil $\mathrm{pH}$, although a slight decrease in $\mathrm{pH}$ (of about 0.2 units) was observed for the two highest doses of SSC and the highest dose of FYM (Figure 1A). 


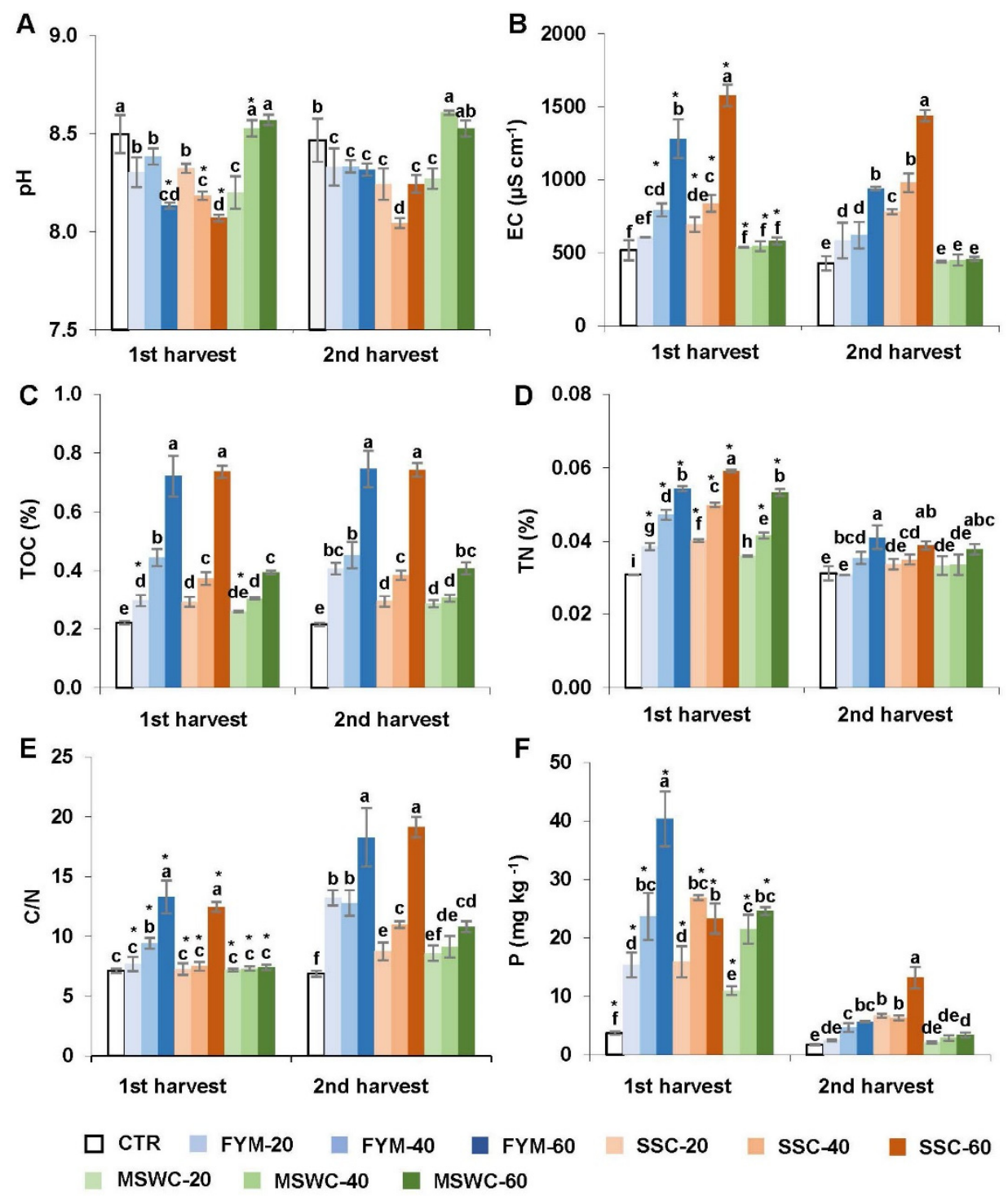

Figure 1. Soil physicochemical parameters: (A) $\mathrm{pH},(\mathbf{B})$ electrical conductivity, (C) total organic carbon, (D) total nitrogen, $(\mathrm{E}) \mathrm{C} / \mathrm{N}$ ratio and $(\mathrm{F})$ available $\mathrm{P}$ in unamended and amended soils. Lower case letters indicate significant differences between treatments within the same harvest time. Asterisks indicate a significant difference between harvest times within each treatment over time $\left({ }^{*} p<0.05\right)$.

The addition of FYM and SSC to the soil caused a significant $(p<0.05)$ and dosedependent increase in soil electrical conductivity relative to the control soil, especially at the higher doses (Figure 1B). At the first harvest, the soil electrical conductivity was 1.5 and 2.5 times higher in the soils amended with FYM-40 and FYM-60 than in the control soil. The SSC induced a greater increase in soil electrical conductivity (3.0-fold increase for SSC-60) than that induced by FYM. In all of the treated soils, the soil electrical conductivity was lower at the second harvest than at the first harvest, although in all cases, it was still higher in the amended soils than in the control soil.

The addition of the three organic amendments to the soils generated a significant $(p<0.05)$ dose-dependent increase in soil organic carbon relative to the control soil, with increases of more than three times for the highest dose $\left(60 \mathrm{t} \mathrm{ha}^{-1}\right)$ (Figure 1C). At the first harvest, the soil organic carbon content was 1.3, 2.0 and 3.3 times higher in the soils amended with, respectively FMY-20, FMY-40 and FMY-60 than in the control soil, and applying SSC caused a similar increase in soil organic C (3.3-fold increase for SSC-60). 
Amendment of the soil with MSWC induced a significantly lower increase in C (2.2fold increase with MSWC-60 rate) than amendment with FYM or SSC. At the second harvest, the increase in organic carbon content relative to the control soil was maintained in all treated soils, and the organic carbon contents of all samples were similar to those observed at the first harvest (Figure 1C).

All three amendments also induced a statistically significant and dose-dependent increase in total soil $\mathrm{N}$ at the first harvest, similar to the three amendments (Figure 1D). The total $\mathrm{N}$ increased 14-23, 26-38 and 42-48\% in soils treated with, respectively, $20 \mathrm{t} \mathrm{ha}^{-1}$, $40 \mathrm{tha}^{-1}$ and $60 \mathrm{tha}^{-1}$ of the amendments. At the second harvest, the total $\mathrm{N}$ content had decreased in all treated soils, although it was generally still significantly higher than in the control soil (up to 34\% for FYM-60). The total N concentrations were similar in all treated soils and related to the applied dose.

The changes in total organic $\mathrm{C}$ and $\mathrm{N}$ contents caused changes in the $\mathrm{C} / \mathrm{N}$ ratio, which underwent a significant, dose-dependent increase in FYM, and SSC amended soils relative to the control soil but did not change in MSWC amended soils at the first harvest (Figure 1E). At the second harvest, a significant and dose-dependent increase in $\mathrm{C} / \mathrm{N}$ content was observed in all treated soils and was generally significantly higher than at the first harvest.

All doses of the three organic residues caused a significant and dose-dependent increase in the soil available $\mathrm{P}(p<0.05)$. The increase was particularly important in FYMamended soil (up to 11-fold), while MSWC and SSC-treated soils showed similar increases (up to 6.7-fold) in available P. The available $\mathrm{P}$ in the soil treated with the highest doses of MSWC and SSC increased to the same level as that for FYM-40. The increase in available P in treated soils did not appear to be related to the P Olsen or total P content of the organic residues (Table 1 and Figure $1 \mathrm{~F}$ ). At the second harvest, the available $\mathrm{P}$ was much lower in all treatments, although in all cases, it was still higher than in the control soil. However, unlike at the first harvest, the available P content was highest in the SSC-treated soil, while the $\mathrm{P}$ availability was lowest in the MSWC-treated soil.

At the first harvest, applying the highest dose of all organic amendments induced a significant increase in the effective CEC (Figure 2A). The observed increase reached 32 and $28 \%$ in FYM and SSC and 22\% in MSWC-amended soils. However, at the second harvest, a positive effect of the amendments on CEC was not detected, except in the soil treated with the highest dose of MSW compost, in which the CEC was $18 \%$ higher than in the control soil. The exchangeable K content of the soil was only significantly higher at the first harvest, following applying manure and the highest dose of SSC (Figure 2B). Exchangeable Ca was also only significantly affected at the first harvest and only with the highest dose of the amendments used (Figure 2C). The addition of the three organic amendments slightly increased the exchangeable $\mathrm{Mg}$ contents (although the change was not always statistically significant). This was observed after both the first and second harvests (Figure 2D). Exchangeable Na was slightly lower at the first harvest after adding the two composts (although the differences were not always statistically significant) (Figure 2E). 

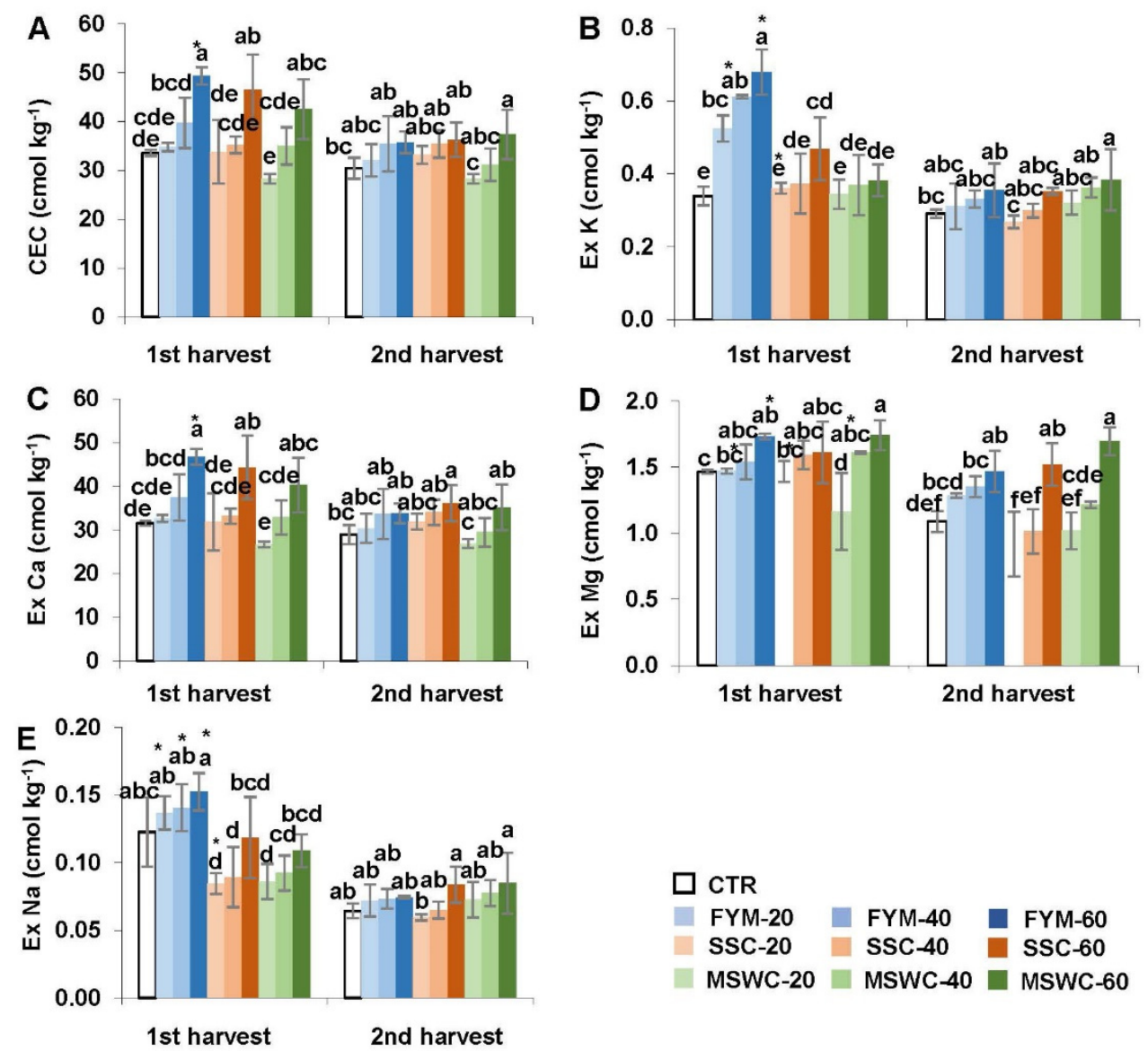

Figure 2. Effects of the three organic waste applications on (A) cation exchange capacity, (B) exchangeable K, (C) exchangeable $\mathrm{Ca}$, (D) exchangeable $\mathrm{Mg}$ and (E) exchangeable Na. Lower case letters indicate significant differences between treatments within the same harvest time. An asterisk indicates significant differences between harvest time within each treatment over time $(* p<0.05)$.

\subsection{Metal Fractionation}

In the present study, pseudo-total $\mathrm{Co}, \mathrm{Cd}, \mathrm{Ni}$, and $\mathrm{Pb}$ concentrations in the control soils were low (Table 1). In general, the amendments did not induce important changes in the concentrations of these elements (Supplementary Table S1), although the pseudo-total concentration of $\mathrm{Cu}$ increased significantly, particularly after applying the highest dose of the organic amendments. The increases reached up to 2.6, 3.6, 3.3-fold in soils treated with FYM, SSC and MSWC, respectively (Figure 3).

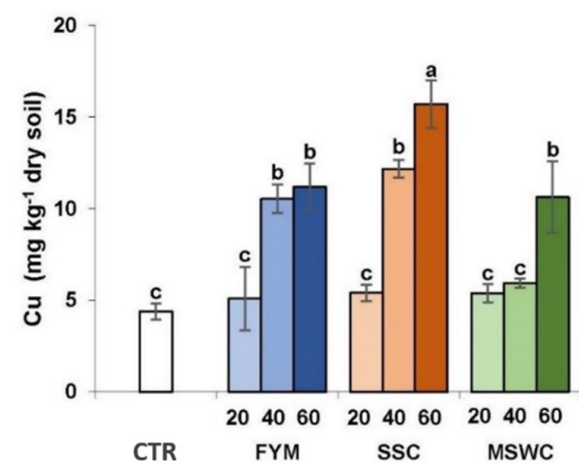

Figure 3. Pseudo-total $\mathrm{Cu}$ concentrations in unamended (CTR) soil and soils amended with different doses $\left(20,40,60 \mathrm{tha}^{-1}\right)$ of farmyard manure (FYM), sewage sludge compost (SSC) or municipal solid waste compost(MSWC).Different letters indicate significant differences between treatments. 
The different fractions of $\mathrm{Cd}, \mathrm{Cr}, \mathrm{Zn}, \mathrm{Pb}, \mathrm{Co}, \mathrm{Cu}$ and $\mathrm{Ni}$ in the control soil and in FYM, MSWC, and SSC amended soils were determined by BCR sequential extraction. However, in both the control and treated soils, $\mathrm{Cd}, \mathrm{Cr}, \mathrm{Zn}$ and $\mathrm{Pb}$ were only found in the residual fraction. Therefore, the soil metal fractionation results are only presented for $\mathrm{Co}, \mathrm{Cu}$ and $\mathrm{Ni}$ (Figure 4). In comparison with the measured pseudo-total concentration of these trace elements in unamended and amended soils, the percentage of recovery with the BCR fractionation was, on average, $108 \pm 22 \%$. Both the minimum and maximum percentage of recovery were observed for $\mathrm{Cu}$.

In the control soils, $\mathrm{Co}, \mathrm{Cu}$ and $\mathrm{Ni}$ were mainly found in the residual fraction, which represented respectively 59, 65 and $83 \%$ of the total content of these elements (Figure 4 ). In general, the amendments had little effect on the trace element fractionation. FYM tended to increase the labile Ni fractions, especially the reducible Ni. A similar effect was observed in the soils amended with SSC, which also slightly increased the reducible Co fraction. The SSC supplied some $\mathrm{Cu}$ to the soil, mainly in oxidizable and residual fractions, but fractionation of this element did not undergo notable changes. The most important changes in fractionation of the elements were observed in the MSW-treated soil. This amendment induced increased labile fractions (acid-extractable and reducible) of Co and Ni. The effect on the reducible fraction (F2) was observed with the medium and high dose of the amendment. Amendment of the soils with MSWC increased the absolute amount and proportion of acid-extractable $\mathrm{Cu}$.

Moreover, this residue also contributed to the absolute amount of residual $\mathrm{Cu}$ in soil, although the proportion of this fraction was lower than in the unamended soil.

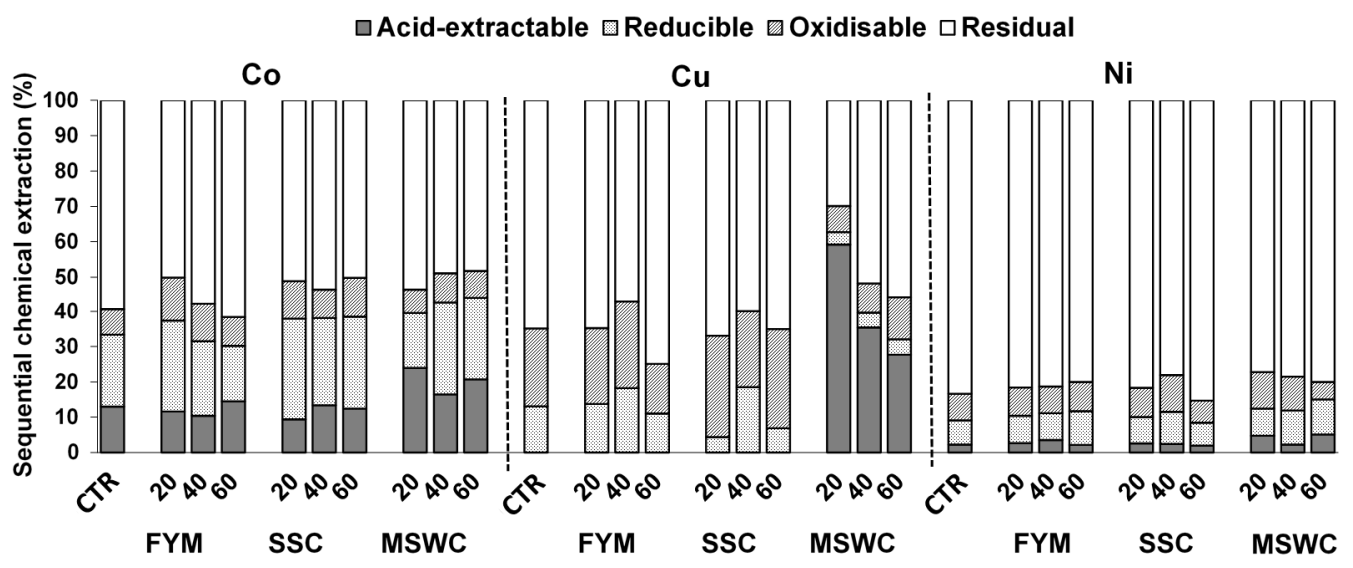

Figure 4. Sequential chemical extraction of $\mathrm{Co}, \mathrm{Cu}$ and $\mathrm{Ni}$ of control soil (CTR) and soils amended with different doses (20, 40, $60 \mathrm{t} \mathrm{ha}^{-1}$ ) of farmyard manure (FYM), sewage sludge compost (SSC) or municipal solid waste compost (MSWC).

\subsection{Effect of Soil Amendments on Grain Yield}

A single application of all three organic amendments (farmyard manure, sewage sludge compost and municipal solid waste compost) significantly increased the barley grain yield, and the positive effect was prolonged over time until the second consecutive harvest analyzed. Generally, and for the three organic amendments, the increase in grain yield was proportional to the application rate. At the first harvest, the yield was lowest in the control plots $\left(1106 \pm 220 \mathrm{~kg} \mathrm{ha}^{-1}\right)$, while the yields were highest in plots treated with the highest dose of the organic amendments; the increases in grain yield reached up to $51 \%$ and were similar for all three organic amendments. The yields obtained with $60 \mathrm{tha}^{-1}$ of FYM, SSC, and MSWC were 2262, 2006 and $1868 \mathrm{~kg} \mathrm{ha}^{-1}$, respectively (Figure 5). Surprisingly, the yield was higher at the second harvest. In all cases, the increase in barley production was proportional to the rate of residue application, and unlike at the first harvest, the increase differed between the three residues. Thus, the maximum barley grain yield was obtained with FYM-60 (6964 $\left.\pm 414 \mathrm{~kg} \mathrm{ha}^{-1}\right)$ followed by SSC-60 $\left(5559 \mathrm{~kg} \mathrm{ha}^{-1}\right)$ and 
MSWC-60 (3738 $\left.\mathrm{kg} \mathrm{ha}^{-1}\right)$, i.e., the yields were 77, 71 and 57\% higher than in the control soil (Figure 5).

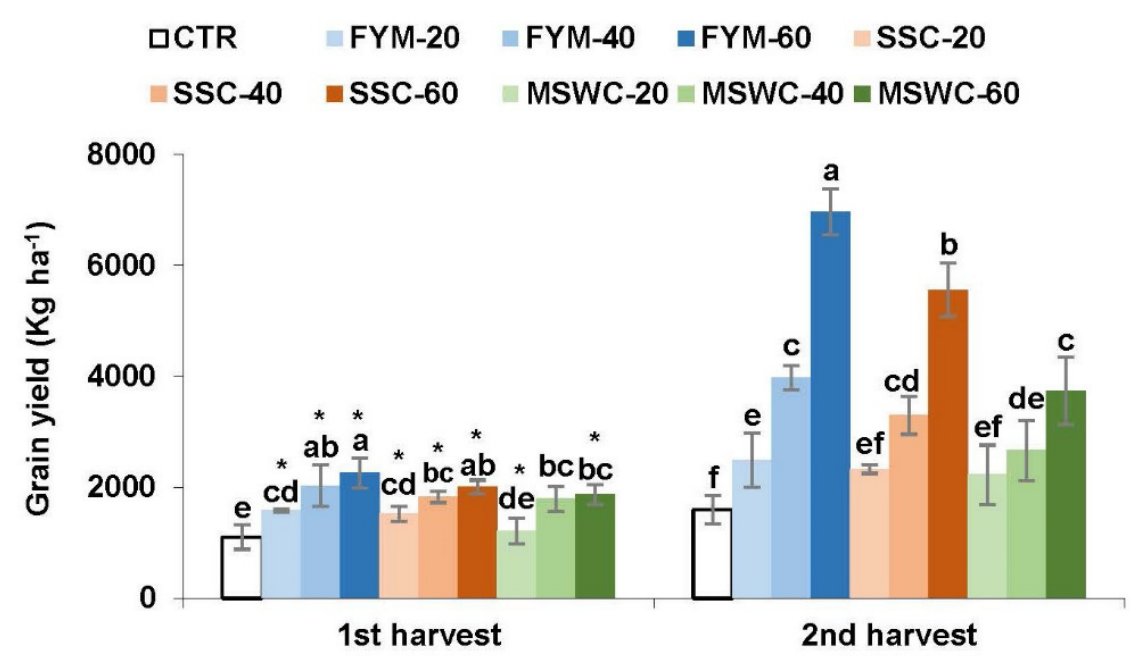

Figure 5. Effect of the soil amendment with different doses $\left(20,40,60 \mathrm{tha}^{-1}\right)$ of farmyard manure (FYM), sewage sludge compost (SSC) or municipal solid waste compost (MSWC). on the barley grain yield. CTR: unamended soil. Lower case letters indicate significant differences between treatments within the same harvest time. An asterisk indicates significant differences between harvest time within each treatment over time $\left({ }^{*} p<0.05\right)$.

\subsection{Effect of Soil Amendment on Plant Nutrient Contents}

The macro- and micronutrients taken up by the barley plants (grain, stem and roots) grown in control soil and in soils amended with farmyard manure, sewage sludge compost and municipal solid waste compost are shown in Figures 6 and 7 and Table 2 and in Supplementary Tables S2 and S3. The contents of all the major nutrients (N, K, Ca and Mg) in the barley plants were significantly affected by all of the organic amendments at both harvest times.
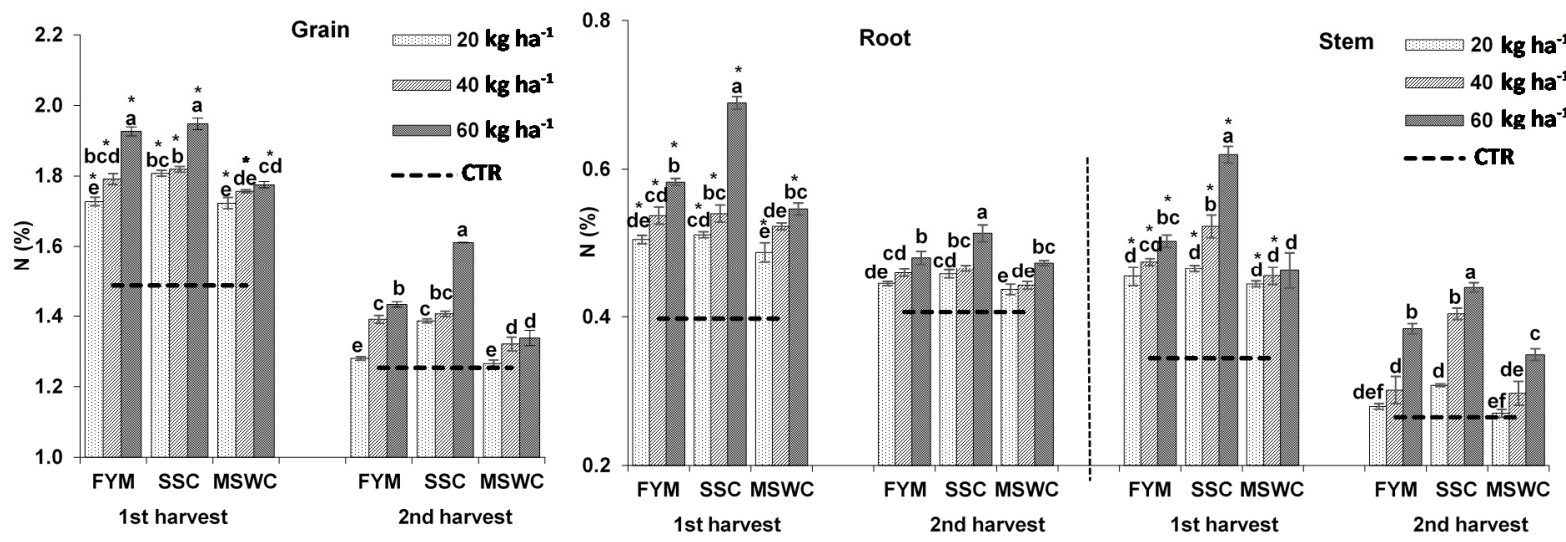

Figure 6. Effects of the soil amendment with different doses $\left(20,40,60 \mathrm{t} \mathrm{ha}^{-1}\right)$ of farmyard manure (FYM), sewage sludge compost (SSC) or municipal solid waste compost (MSWC) on N contents in barley grains, stems and roots. CTR: unamended soil. Lower case letters indicate significant differences between treatments within the same harvest time. Asterisks indicate significant differences between harvest time within each treatment over time $\left.{ }^{*} p<0.05\right)$. 

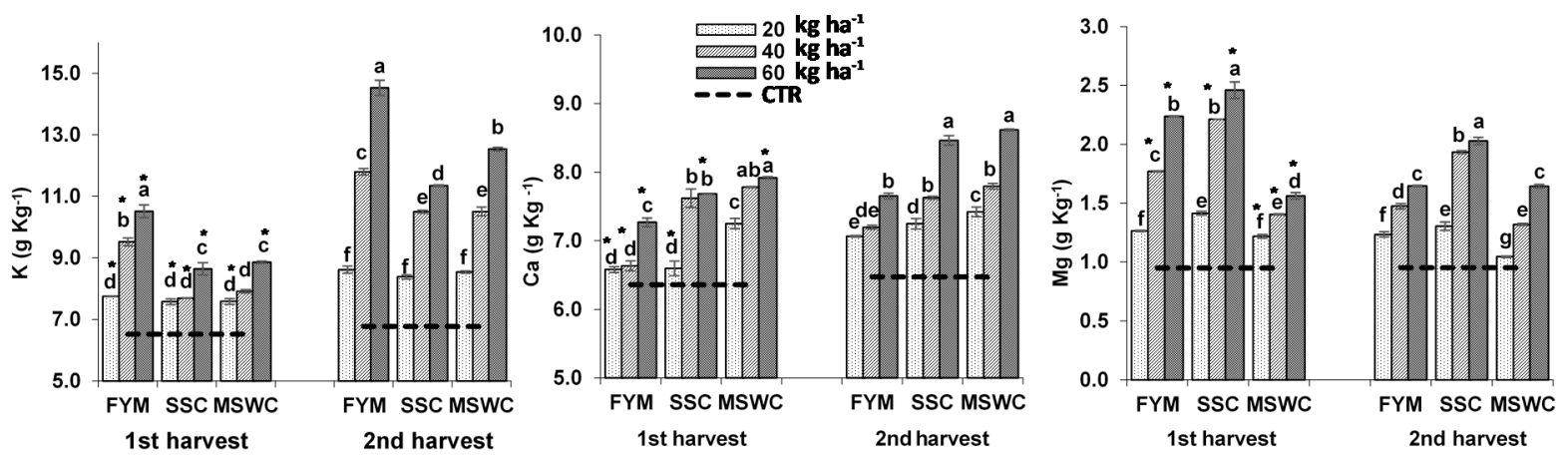

Figure 7. Effects of the soil amendment with different doses $\left(20,40,60 \mathrm{t} \mathrm{ha}^{-1}\right)$ of farmyard manure (FYM), sewage sludge compost (SSC) or municipal solid waste compost (MSWC) on K, Ca and Mg concentrations in barley stems. CTR: unamended soil. Lower case letters indicate significant differences between treatments within the same harvest time. Asterisks indicate significant differences between harvest time within each treatment over time $\left({ }^{*} p<0.05\right)$.

Table 2. Effects of the soil amendment with different doses $\left(20,40,60 \mathrm{tha}^{-1}\right)$ of farmyard manure (FYM), sewage sludge compost (SSC) or municipal solid waste compost (MSWC) on some micronutrient concentrations in stems of barley plants (mean, $n=3$ ). CTR: unamended soil. Lower case letters indicate significant differences between treatments within the same harvest time. An asterisk indicates significant differences between harvest time within each treatment over time. ${ }^{*} p<0.05$, ${ }^{* *} p<0.01,{ }^{* * *} p<0.001$.

\begin{tabular}{|c|c|c|c|c|c|}
\hline & & $\mathrm{Fe}\left(\mathrm{mg} \mathrm{kg}{ }^{-1}\right)$ & Mn (mg kg $\left.{ }^{-1}\right)$ & $\mathrm{Zn}\left(\mathrm{mg} \mathrm{kg}^{-1}\right)$ & $\mathrm{Cu}\left(\mathrm{mg} \mathrm{kg}^{-1}\right)$ \\
\hline \multicolumn{6}{|c|}{ 1st harvest } \\
\hline CTR & 0 & $128.4 \pm 4.2 \mathrm{e}^{* * *}$ & $6.3 \pm 0.1 \mathrm{f}$ & $11.1 \pm 0.0 \mathrm{e}^{* * *}$ & $4.0 \pm 0.5 \mathrm{e}^{* *}$ \\
\hline \multirow{3}{*}{$\begin{array}{c}\text { FYM } \\
\left(\mathrm{t} \mathrm{ha}^{-1}\right)\end{array}$} & 20 & $158.4 \pm 5.5 \mathrm{de}^{* *}$ & $6.5 \pm 0.3 \mathrm{f}^{* * *}$ & $10.5 \pm 0.4 \mathrm{e}$ & $2.6 \pm 0.3 \mathrm{f}$ \\
\hline & 40 & $130.7 \pm 3.1 \mathrm{e}^{* * *}$ & $12.2 \pm 0.6 \mathrm{~d}$ & $12.3 \pm 1.0 \mathrm{de}$ & $3.0 \pm 0.2$ ef \\
\hline & 60 & $242.5 \pm 12.9 \mathrm{~b}$ & $15.6 \pm 0.1 \mathrm{a}^{* * *}$ & $15.5 \pm 0.0 \mathrm{bc} * * *$ & $3.8 \pm 0.1$ ef $* *$ \\
\hline \multirow{3}{*}{$\begin{array}{c}\text { SSC } \\
\left(\mathrm{t} \mathrm{ha}^{-1}\right)\end{array}$} & 20 & $161.0 \pm 15.0 \mathrm{de}^{*}$ & $8.2 \pm 0.4 \mathrm{e}$ & $13.2 \pm 1.4 \mathrm{~d}^{*}$ & $5.6 \pm 1.0 \mathrm{~d}^{* *}$ \\
\hline & 40 & $166.8 \pm 3.3 \mathrm{~d}^{* * *}$ & $13.6 \pm 0.0 c^{* *}$ & $15.4 \pm 0.3 \mathrm{bc} *$ & $8.2 \pm 1.1 \mathrm{bc} * *$ \\
\hline & 60 & $210.2 \pm 21.4 \mathrm{bc}$ & $14.7 \pm 0.8 \mathrm{~b}$ & $17.6 \pm 0.8 \mathrm{a}^{*}$ & $10.3 \pm 0.9 \mathrm{a}^{* * *}$ \\
\hline \multirow{3}{*}{$\begin{array}{l}\text { MSWC } \\
\left(\mathrm{t} \mathrm{ha}^{-1}\right)\end{array}$} & 20 & $185.7 \pm 29.5 \mathrm{~cd}$ & $12.6 \pm 0.7 \mathrm{~d}$ & $11.2 \pm 0.3 \mathrm{e}$ & $7.1 \pm 0.6 c^{* * *}$ \\
\hline & 40 & $232.8 \pm 22.4 \mathrm{~b}$ & $13.7 \pm 0.1 c^{* *}$ & $15.1 \pm 1.3 c^{*}$ & $9.1 \pm 0.7 \mathrm{ab}{ }^{* * *}$ \\
\hline & 60 & $286.9 \pm 31.7 \mathrm{a}^{*}$ & $13.9 \pm 0.8 \mathrm{bc} *$ & $17.0 \pm 1.7 \mathrm{ab}$ & $9.8 \pm 0.9 \mathrm{a}^{* * *}$ \\
\hline \multicolumn{6}{|c|}{ 2nd harvest } \\
\hline CTR & 0 & $94.1 \pm 3.0 \mathrm{f} * * *$ & $7.2 \pm 0.2 \mathrm{~d}$ & $10.2 \pm 0.1 \mathrm{e}^{* * *}$ & $2.1 \pm 0.1 \mathrm{~d}^{* *}$ \\
\hline \multirow{3}{*}{$\begin{array}{c}\text { FYM } \\
\left(\mathrm{t} \mathrm{ha}^{-1}\right)\end{array}$} & 20 & $103.7 \pm 2.6 f^{* * *}$ & $11.0 \pm 0.2 b^{* * *}$ & $10.3 \pm 0.2 \mathrm{e}$ & $2.3 \pm 0.1 \mathrm{~d}$ \\
\hline & 40 & $212.7 \pm 6.2 c^{* * *}$ & $11.3 \pm 0.3 \mathrm{~b}$ & $12.3 \pm 0.9 \mathrm{~d}$ & $3.2 \pm 0.1 \mathrm{bc}$ \\
\hline & 60 & $223.8 \pm 9.0 \mathrm{abc}$ & $12.9 \pm 0.2 a^{* * *}$ & $14.2 \pm 0.1 c^{* * *}$ & $3.4 \pm 0.1 b^{* *}$ \\
\hline \multirow{3}{*}{$\begin{array}{c}\text { SSC } \\
\left(\mathrm{t} \mathrm{ha}^{-1}\right)\end{array}$} & 20 & $130.9 \pm 7.4 \mathrm{e}^{*}$ & $8.7 \pm 0.3 c$ & $10.5 \pm 0.4 \mathrm{e}^{*}$ & $2.6 \pm 0.4 \mathrm{~cd}^{* *}$ \\
\hline & 40 & $216.4 \pm 5.8 \mathrm{bc}^{* * *}$ & $10.9 \pm 0.8 b^{* *}$ & $13.1 \pm 0.9 \mathrm{~d}^{*}$ & $3.3 \pm 0.2 b^{* *}$ \\
\hline & 60 & $227.2 \pm 2.7 \mathrm{ab}$ & $13.1 \pm 0.9 \mathrm{a}$ & $18.9 \pm 0.1 \mathrm{a}^{*}$ & $4.9 \pm 0.5 a^{* * *}$ \\
\hline \multirow{3}{*}{$\begin{array}{l}\text { MSWC } \\
\left(\mathrm{t} \mathrm{ha}^{-1}\right)\end{array}$} & 20 & $171.7 \pm 11.0 \mathrm{~d}$ & $11.3 \pm 0.7 \mathrm{~b}$ & $10.4 \pm 1.1 \mathrm{e}$ & $3.2 \pm 0.3 b^{* * *}$ \\
\hline & 40 & $221.5 \pm 10.2 \mathrm{abc}$ & $11.5 \pm 0.6 b^{* *}$ & $12.5 \pm 0.3 \mathrm{~d}^{*}$ & $3.5 \pm 0.2 b^{* * *}$ \\
\hline & 60 & $231.9 \pm 3.5 \mathrm{a}^{*}$ & $11.8 \pm 0.8 b^{*}$ & $16.0 \pm 0.2 \mathrm{~b}$ & $3.7 \pm 0.7 b^{* * *}$ \\
\hline
\end{tabular}

Application of the three amendments caused a statistically significant and dosedependent increase in nitrogen content in the three plant compartments analyzed (grain, stem and root) at the first harvest (Figure 6). The effect was more pronounced in the stem and root parts than in the grain and was generally higher for SSC and FYM than with MSWC. The N content of the grain, stem and root increased by up to 31,80 and $73 \%$, respectively, in SSC amended soil, and by up to 19, 34 and 37\%, respectively, in soil treated with MSWC. The increase in N content induced by FYM was up to $30 \%$ in grain and up to $46 \%$ in stem and root. At the second harvest, the $\mathrm{N}$ concentration in barley plants decreased in all treated soils, although in most cases, it remained significantly higher than in control soil. The increase in $\mathrm{N}$ content of plants grown in soils treated with $60 \mathrm{tha}^{-1}$ 
of SSC reached up to 29,66 and $26 \%$ in grain, stem and root parts, respectively, while the maximum increases induced by FYM and MSWC were lower (Figure 6).

In general, the $\mathrm{K}, \mathrm{Ca}$ and $\mathrm{Mg}$ concentrations in the plant tissues were positively affected by the organic residues applied to soil, and the effect observed was also dosedependent (Figure 7 and Table S2). The magnitude of the effect induced by the different amendments depended on the nutrient and on the plant tissue considered. At the first harvest, the greatest improvements in the stem nutrients corresponded to FYM for K (up to $61 \%$ increase), SSC and MSWC for Ca (up to $24 \%$ increase), and FYM and SSC for $\mathrm{Mg}$ (up to 1.6-fold increase) (Figure 7) and in the case of root, the higher increases were generally obtained with FYM and SSC (increases of up to $60 \%$ in K content and of up to 1.9 and 2.5-fold in Ca and Mg contents, respectively) (Table S2). FYM and SSC had a similar effect on grain nutrients, increasing $\mathrm{K}$ and $\mathrm{Mg}$ concentrations by up to 1.2-fold and 78\%, respectively, while the improvement induced by MSWC was lower (up to 83 and $75 \%$, respectively). The soil amendments also tended to increase the Ca content of the grain (the effect was only significant for the highest dose of SSC) (Table S2). In general, the positive effect of the organic residues on plant nutrients was maintained or was even more pronounced at the second harvest. The increase in $\mathrm{K}, \mathrm{Ca}$ and $\mathrm{Mg}$ concentrations in grains (up to 2.7, 3.9 and 1.9-fold, respectively) and in $\mathrm{K}$ concentrations in roots and stems (up to 1.1 and 2.4-fold) from plants grown in amended soils was much higher than at the first harvest (Figure 7 and Table S2). The exception was the Mg concentration in roots of plants grown in amended soils, the values of which were generally similar to or lower than in plants grown in unamended soils.

The organic residues generally had a dose-dependent positive effect on the micronutrients analyzed in the barley plants (Table 2 and Table S3). At the first harvest, the greatest increases in $\mathrm{Fe}$ and $\mathrm{Zn}$ were observed in the roots of plants grown in soils treated with MSWC and SSC (up to 4.3 and 1.4-fold, respectively), and the greatest increases in Mn were detected in the stems (up to 1.5-fold in FYM amended soils). The increase in these micronutrients in the grain was less pronounced than in root or stem, and the increase in $\mathrm{Zn}$ was generally not significant. However, the increase in $\mathrm{Cu}$ content was more pronounced in the grain (up to 3 times in soils treated with $60 \mathrm{tha}^{-1}$ of SSC) than in other plant compartments. The positive effect of the amendments on the micronutrients considered was generally maintained at the second harvest. In some cases, e.g., Fe in stems and $\mathrm{Zn}$ and $\mathrm{Cu}$ in roots, the increases were higher than detected at the first harvest.

\section{Discussion}

\subsection{Effects of Soil Amendments on Soil Physicochemical Properties}

Despite the statistically significant decrease in $\mathrm{pH}$ in the soils treated with manure and sewage sludge compost, the $\mathrm{pH}$ values remained similar to those in untreated soils. The observed increase is unlikely to have had a significant impact on crop production or soil performance. Likewise, despite the slight increase in EC in amended soils, the observed values (up to $1577 \mu \mathrm{S} \mathrm{cm}^{-1}$ in SSC-60 plot) are far from the $\geq 4000 \mu \mathrm{S} \mathrm{cm}^{-1}$ that would pose a risk of salinization [35].

Soil organic matter (SOM) is considered a key indicator of soil quality and can be enhanced by the addition of organic wastes [10,36]; mineralization of the SOM covers the major reserves of essential nutrients for plants [37]. As expected, and consistent with previous findings in several soils in arid regions $[38,39]$, farmyard manure, municipal solid waste compost and sewage sludge compost amendments increased the total organic carbon content of the soils, and the increase was proportional to the amount of residue applied. The three amendments also effectively maintained elevated soil organic matter levels, as the increases remained after two consecutive harvests (Figure 1C). The differences in the organic carbon content of amended soils can be attributed to the chemical composition, and decomposability of the residues applied. The FYM had relatively high $\mathrm{C}$ and $\mathrm{N}$ contents (23.6 and $1.2 \%$, respectively) but also a high $\mathrm{C} / \mathrm{N}$ ratio (23). The $\mathrm{C}$ content of SSC was similar to that of FYM, but the former had a higher total $\mathrm{N}$ content and lower $\mathrm{C} / \mathrm{N}$ ratio 
(12); therefore, SSC can be considered more balanced than FYM concerning the $\mathrm{C}$ and $\mathrm{N}$ contents [40]. The $\mathrm{C} / \mathrm{N}$ ratio, among many other factors, could affect the rate of organic matter decomposition and the amount of $\mathrm{N}$ released, as mineralization is often limited in composts in which the $\mathrm{C} / \mathrm{N}$ ratio is high $(>15)$ [41].

In the present study, the positive effect of FMY on soil $\mathrm{N}$ was relatively low and not related to the dose applied (Figure 1D). By contrast, amendment of the soil with SSC led to a significant, dose-dependent increase in the $\mathrm{N}$ content. However, despite the well-balanced $\mathrm{C}$ and $\mathrm{N}$ contents in SSC, the soil N content decreased after the second crop harvest in both soils treated with FMY or SSC. The organic matter content was much lower (around one-third) in MSWC than in the other two amendments. However, this residue's addition to soil led to a slight, dose-dependent increase in total C and N contents; surprisingly, the soil $\mathrm{C}$ content remained elevated even after the second harvest. Considering the $\mathrm{C}$ and $\mathrm{N}$ contents of the three organic amendments evaluated, increases in $\mathrm{C}$ and $\mathrm{N}$ concentrations in soils treated with the highest dose of MSWC $\left(60 \mathrm{tha}^{-1}\right)$ could be expected to be similar to those in soils treated with the lowest doses of FYM or SSC $\left(20 \mathrm{tha}^{-1}\right)$. However, MSWC induced greater increases in soil organic matter than expected, which could be attributed to better incorporation of the residue within the soil matrix. The decrease in soil $\mathrm{N}$ detected in all amended soils after the second harvest suggests depletion of $\mathrm{N}$ reserves due to $\mathrm{N}$ uptake by the plants. Other $\mathrm{N}$ losses cannot be ruled out, as the soil properties (high $\mathrm{pH}$ and high sand content) and the environmental conditions (irrigation, high insolation) would favor nitrification and the potential leaching of $\mathrm{NO}_{3}{ }^{-}$, as well as ammonium volatilization [42].

All three organic residues increased the available $\mathrm{P}$ concentrations at the first harvest. The observed effect appears to be closely related to the amount of available $\mathrm{P}$ present in the different amendments (much higher in FYM and SSC than in MSWC, Table 1). Increases in the available $P$ content after applying organic residues have also been reported in other studies [43-45] and have been attributed to the addition of $P$ through compost over the amount removed by the crop [36]. However, the levels of available P decreased sharply at the second harvest (Figure 1F), probably because P uptake by plants in the second year was not compensated by inorganic $P$ released from residues.

Cation exchange capacity is a key soil chemical property that mainly depends on clay and organic matter contents [46]. In the present study, the addition of all three amendments increased the total CEC and the exchangeable $\mathrm{K}, \mathrm{Ca}$ and $\mathrm{Mg}$ contents; this finding is consistent with similar increases observed after the addition of municipal biosolids or farm manure in other fields studies [47,48]. The increased CEC has been attributed to increased negatively charged surfaces present in the organic matter of the amendments [14,49].

\subsection{Effects of Organic Amendments on Trace Metals Distribution in Soils}

The total trace metal contents of the three organic residues were below the maximum amounts permitted by legislation (due to the lack of legislation regulating the amounts of trace elements permitted in Tunisian soils, EU thresholds are used as a reference, [50]. It is widely accepted that the measurement of total metal concentrations is insufficient for accurate assessment of the potential risk of soil contamination [18]. Chemical speciation of trace elements in the soil must be carried out to determine the mobility and bioavailability of the elements and the associated potential hazards [51]. Sequential extraction is widely used to evaluate the redistribution of geochemical forms of elements in diverse soil fractions and thus estimate the bioavailability of the elements. In this study, $\mathrm{Co}, \mathrm{Cu}$ and $\mathrm{Ni}$ in control soils were mainly (more than $80 \%$ ) present in residual forms related to the crystalline structure of silicate minerals [52]. This residual fraction is considered non-mobile and not available to plants [53] and thus safe from an environmental point of view. Regarding the extractable fractions of the elements, the highest proportion of Co occurred in reducible forms. Extractable $\mathrm{Cu}$ was only present in reducible and oxidizable forms; the extractable fraction of $\mathrm{Ni}$ occurred in reducible and oxidizable forms, while only $2.2 \%$ of $\mathrm{Ni}$ was present in the acid-extractable fraction. 
Amendment of soil with FYM slightly increased the total $\mathrm{Cu}$ and $\mathrm{Zn}$ contents, but the distribution of metals in the different fractions was generally not affected by the addition of manure. In some FYM-amended soils, the proportion of extractable forms of Cu increased slightly, but the increase was not related to the dose of FYM (Figure 4). The results are consistent with those of previous studies, which did not detect significant alterations in the chemical speciation of trace elements in soil due to the addition of manure, even after repeated application [54].

As in FYM, the addition of SSC did not strongly affect extractable $\mathrm{Cu}, \mathrm{Co}$ and $\mathrm{Ni}$; however, the proportion of the oxidizable forms of $\mathrm{Cu}$ and $\mathrm{Ni}$ tended to increase after the addition of this amendment. This fraction corresponds to organically bound trace elements and reflects the high affinity of these elements for organic matter [16,51]. Ref. [16] also observed an increased oxidizable $\mathrm{Cu}$ fraction in sewage sludge-amended soils.

Unlike FYM and SSC, the addition of MSWC affected the distribution of several elements, especially $\mathrm{Co}$ and $\mathrm{Cu}$. This amendment increased the extractability of these elements, which was generally highest with the lowest doses of MSWC applied (Figure 4). Moreover, the fractions in which the increases were greatest were generally the acidextractable forms, which may imply an increase in their availability to plants or potential leachability [51]. The observed modification was particularly remarkable for $\mathrm{Cu}$, as the acid-extractable fraction was negligible in the unamended soils and represented between 40 and $60 \%$ of the $\mathrm{Cu}$ content in MSWC-amended soils. Regarding other trace elements of major environmental concern, the concentrations of $\mathrm{Pb}$ in the amended soils (maximum $6.6 \pm 0.2 \mathrm{mg} \mathrm{kg}^{-1}$ soil) were far from the limits established (generally $50-300 \mathrm{mg} \mathrm{kg}^{-1}$ soil) by the EU and national legislation of European countries [55]. The amendments tended to slightly increase the Cd concentration, which remained lower than the threshold values indicated in most regulations [55]. Moreover, this trace element was not present in detectable amounts in the plant compartments analyzed. The slight modification of the element speciation observed in soils treated with high doses of compost requires further investigation. In summary, concerning the distribution of trace metals in soil and from an environmental point of view, the effect of SSC was similar to that of FYM; however, MSWC induced increased bioavailability of some elements and using this type of amendment should be closely monitored. The potential accumulation of certain trace elements in the soil after repeated application of organic amendments reinforces the importance of studies analyzing their medium-term performance to exploit their fertilizing potential and minimize the doses applied to the soil.

\subsection{Effect of Organic Amendments on Grain Yield and Plant Nutrient Contents}

The positive effects of the three organic amendments addition on soil organic matter and nutrients contents were clearly reflected in the growth and development of barley plants and explain the significant improvement in grain yield. The findings are consistent with similar increases in crop production reported for arid and semiarid soils amended with diverse organic residues [56,57], including Tunisian calcareous soils similar to that considered in the present study [27]. In the present study, the positive effect on grain yield was much higher at the second harvest, indicating a medium to a long-term increase in fertility induced by the amended soils' organic matter and nutrients content.

The crop improvement detected at the second harvest is consistent with the findings of [58], who reported improvement of wheat yield parameters in the second than in the first experimental season after soil amendment. These authors attributed the increase in wheat productivity to the residual effect of the organic matter applied in the first season. Other authors mention the role of macro- and micronutrients provided by compost in stimulating metabolic processes, promoting growth, and increasing the synthesis and accumulation of more metabolites in plant tissues [59]. In the present study, both mechanisms may have acted simultaneously, as the increase in organic matter content and nutrients resulting from the addition of the organic amendments was maintained in the second year of the experiment. At both the first and the second harvests, the grain yield was highest in the 
soils treated with FYM (Figure 5). At the first harvest, the highest dose of MSWC induced improvements similar to the lowest dose of FYM or SSC; however, at the second harvest, MSWC was one of the best amendments and induced higher increases in grain yield higher than SSC.

As most of the soil macronutrients increased rapidly after the addition of organic residues, positive effects on plant nutrient contents were observed during the study period. In all cases, a dose-dependent increase in plant nutrients was observed after the addition of organic amendments. Significant increases in $\mathrm{N}, \mathrm{Ca}, \mathrm{K}$, and $\mathrm{Mg}$ contents in barley plants were observed at both the first and the second harvest, though in the latter case, the concentrations of these nutrients were generally lower than at the first harvest. The increases in nutrient contents of the plants growing in soils amended with FYM, SSC and MSWC are consistent with the findings of other studies [60,61]. Moreover, authors such as ref. [62] reported that composting of sewage sludge might decrease the release of mineral nitrogen (by half). Depending on compost dose and quality, the nitrogen supplied may be sufficient for plant demand, but only in the season directly following compost application. Therefore, in the second year, both the soil $\mathrm{N}$ and the $\mathrm{N}$ content of the plants would decrease.

Potassium is one of the most important essential plant nutrients, and its accumulation in barley plants was significantly augmented by the addition of organic residues, especially at the second harvest. Ref. [63] explained such increases by the high residual amount of potassium bound by clay minerals and organic matter in compost-amended soil; the bound potassium then becomes more available due to the action of organic acids released during decomposition.

In the present study, the addition of organic residues increased Ca concentrations and maintained high $\mathrm{Mg}$ concentrations in barley plants. In an earlier study ref. [64] showed that $\mathrm{Ca}$ and $\mathrm{Mg}$ concentrations were higher in the grains of wheat grown in soils amended with sewage sludge compost than in the plants grown in soils treated with chemical fertilizer. Similarly, ref. [65] found that compost application caused a significant increase in $\mathrm{Ca}$ and $\mathrm{Mg}$ concentrations in shoots and roots of ryegrass consistent with dry matter accumulation. Amendment with municipal solid waste compost has been shown to increase $\mathrm{Mg}$ concentrations in blueberry leaves compared to the amount of municipal solid waste compost added to the soil [66].

Concentrations of Fe and Mn were also increased in barley plants grown on plots amended with farmyard manure and the two composts, relative to plants grown in control plots. Similar results were also reported by [67], who found that application of farmyard manure and compost to soil produced plants enriched in Fe and Mn relative to the plants grown in untreated soil, while [68] reported a similar finding in maize plants growing in a sandy loam soil amended with municipal solid waste compost.

Apart from boosting nutrient levels, composts are considered as the principal source of heavy metal input in agricultural soils, which is of environmental concern due to the toxicity of these metals to plants. Heavy metals are considered one of the major toxic pollutants due to their long persistence in the environment. The presence of large amounts of heavy metals in composts could lead to heavy metal accumulation in soils and plants, thereby contaminating the food chain and groundwater and threatening human health and the environment [69]. In the present study, a significant, dose-dependent increase in concentrations of $\mathrm{Cu}$ and $\mathrm{Zn}$ was observed in barley plants growing in the soils amended with organic amendments relative to the plants grown in control plots. In the case of $\mathrm{Zn}$, the increase was even higher at the second than in the first harvest, while the opposite was observed for $\mathrm{Cu}$. Nevertheless, the amounts of $\mathrm{Cu}$ and $\mathrm{Zn}$ accumulated in the plants were within the permissible levels, as defined by [70]. These authors reported phytotoxic limits of between 20 and $100 \mathrm{mg} \mathrm{kg}^{-1}$ for $\mathrm{Cu}$ and between 100 and $400 \mathrm{mg} \mathrm{kg}^{-1}$ for $\mathrm{Zn}$, which are much higher than the amounts detected in this study. It is also worth mentioning that the increase in soil $\mathrm{Cu}$ bioavailability induced by MSWC (Figure 4) was not reflected by the concentrations of this element detected in the barley plants. For the three doses of MSWC 
considered, the total amount of $\mathrm{Cu}$ accumulated in barley plants was similar or even lower than the amount of $\mathrm{Cu}$ accumulated in barley growing in the soils amended with FYM and SSC. This suggests that the amendment of soil with MSWC does not increase the toxicity of $\mathrm{Cu}$ to the plants.

\section{Conclusions}

The positive effects of a single application of the amendments on both the soil fertility and the barley yield and nutritive status indicate that cheap, highly available organic amendments, such as sewage sludge compost and municipal solid waste compost, may be suitable as substitutes for farmyard manure, and help to solve the shortage and increasing cost of the organic amendment typically applied to arid and semiarid soils in Tunisia. The analysis of the distribution of heavy metals in soil fractions and the observed improvements of fertility and crop yield in amended soils demonstrate the value of recycling organic wastes in agricultural soils as a sustainable method of waste management. The findings confirm the interest in the medium and long-term monitoring of soil and crop properties after a single application of the organic amendment to determine the capacity of this type of residue to release plant nutrients slowly and thus prolong the beneficial effects. The study displays interesting areas of research aimed at exploring combinations of the organic amendments for taking maximum advantage of their fertilizing capacity and availability.

Supplementary Materials: The following are available online at https:/ /www.mdpi.com/article/10 .3390 /agriculture11050415/s1, Table S1: Pseudo-total concentration of trace elements (average \pm SD) in unamended soil and in soils amended with different doses of FYM, SSC or MSWC. Asterisks indicate significant differences from the content in the soil amended with the lowest dose of farmyard manure. Table S2: Effects of applying the amendments on some macronutrient concentrations in grain and root of barley plants (mean, $n=3$ ). Lower case letters indicate significant differences between treatments within the same harvest time. An asterisk indicates significant differences between harvest time within each treatment over time. ${ }^{*} p<0.05,{ }^{* *} p<0.01,{ }^{* * *} p<0.001$, Table S3: Effects of applying the amendments on some micronutrient concentrations in barley grains and roots (mean, $n=3$ ). Lower case letters indicate significant differences between treatments within the same harvest time. Asterisks indicate significant differences between harvest time within each treatment over time. ${ }^{*} p<0.05,{ }^{* *} p<0.01,{ }^{* * *} p<0.001$.

Author Contributions: Conceptualization, H.O. and P.S.K.; methodology, H.O. and B.R.-G.; validation, M.M., Á.P.-F. and C.T.-C.; formal analysis, R.I.Z.; investigation, K.A.; resources, M.M. and P.S.K.; data curation, H.O., B.R.-G.; writing-original draft preparation, H.O.; writing-review and editing, Á.P.-F., C.T.-C. and M.M.; visualization, H.O., Á.P.-F. and C.T.-C.; supervision, M.M.; project administration, M.M.; funding acquisition, H.O. and P.S.K. All authors have read and agreed to the published version of the manuscript.

Funding: This research was funded by the Tunisian Ministry of Higher Education and Scientific Research, the University of Gabès (Tunisia) and the Axencia Galega de Innovación of the Autonomous Government Galicia (Spain) (grant reference IN607A 2017/6).

Acknowledgments: This article is dedicated to the memory of Petra Kidd (1972-2020), who was taken from us too soon and is dearly missed. Her dedication, enthusiasm and generosity were an essential contribution to this research and will always be an inspiration to us. We are grateful to the staff at the Eremology and Combating Desertification Laboratory, IRA (Medenine) (LR16IRA01), and at the Soil Biochemistry Department of the IIAG-CSIC (Santiago de Compostela) for their helpful collaboration. We thank Lucia Debernardo Espiñeira and Mohamed Dbara for technical assistance and Christine Francis for the revision of the English language.

Conflicts of Interest: The authors declare no conflict of interest.

\section{References}

1. Brahim, N.; Ibrahim, H.; Hatira, A. Tunisian soil organic carbon stock: Spatial and vertical variation. Procedia. Eng. 2014, 69, 1549-1555. [CrossRef]

2. Garcia, C.; Hernandez, T.; Coll, M.; Ondono, S. Organic amendments for soil restoration in arid and semiarid areas: A review. AIMS Environ. Sci. 2017, 4, 640-676. [CrossRef] 
3. Liang, X.; Chen, B.; Nie, X.; Shi, Z.; Huang, X.; Li, X. The distribution and partitioning of common antibiotics in water and sediment of the Pearl River Estuary, South china. Chemosphere 2013, 92, 1410-1416. [CrossRef] [PubMed]

4. Chen, J.H. The combined use of chemical and organic fertilizers and/or biofertilizer for crop growth and soil fertility. In Proceedings of the International Workshop on Sustained Management of the Soil-Rhizosphere System for Efficient Crop Production and Fertilizer Use, Bangkok, Thailand, 16-20 October 2006; pp. 1-11.

5. Eid, E.M.; Alrumman, S.A.; El-Bebany, A.F.; Hesham, A.E.; Taher, M.A.; Fawy, K.F. The effects of different sewage sludge amendment rates on the heavy metal bioaccumulation, growth and biomass of cucumbers (Cucumis sativus L). Environ. Sci. Pollut. Res. Int. 2017, 24, 16371-16382. [CrossRef] [PubMed]

6. Chen, Y.; Camps-Arbestain, M.; Shen, Q.; Singh, B.; Cayuela, M.L. The long-term role of organic amendments in building soil nutrient fertility: A meta-analysis and review. Nutr. Cycl. Agroecosyst. 2018, 111, 103-125. [CrossRef]

7. Lakhdar, A.; Scelza, R.; Scotti, R.; Rao, M.A.; Jedidi, N.; Gianfreda, L.; Abdelly, C. The effect of compost and sewage sludge on soil biological activities in salt-affected soil. Rev. Cienc. Suelo Y Nutr. Veg. 2010, 10, 40-47. [CrossRef]

8. Diacono, M.; Montemurro, F. Long-term effects of organic amendments on soil fertility. A review. Agron. Sustain. Dev. 2010, 30, 401-422. [CrossRef]

9. Ben Achiba, W.; Gabteni, N.; Lakhdar, A.; Du Laing, G.; Verloo, M.; Jedidi, N.; Gallali, T. Accumulation and fractionation of trace metals in a Tunisian calcareous soil amended with farmyard manure and municipal waste compost. J. Hazard. Mater. 2010, 176, 99-108. [CrossRef]

10. Hamdi, H.; Hechmi, S.; Khelil, M.N.; Zoghlami, I.R.; Benzarti, S.; Mokni-Tlili, S.; Hassen, A.; Jedidi, N. Repetitive land application of urban sewage sludge: Effect of amendment rates and soil texture on fertility and degradation parameters. Catena 2019, 172, 11-20. [CrossRef]

11. Mujdeci, M.; Isildar, A.A.; Uygur, V.; Alaboz, P.; Unlu, H.; Senol, H. Cooperative effects of field traffic and organic matter treatments on some compaction-related soil properties. Solid Earth 2017, 8, 189-198. [CrossRef]

12. Aggelides, S.M.; Londra, P.A. Effects of compost produced from town wastes and sewage sludge on the physical properties of a loamy and clay soil. Bioresour. Technol. 2000, 71, 253-259. [CrossRef]

13. Lakhdar, A.; Hafsi, C.; Rabhi, M.; Debez, A.; Montemurro, F.; Abdelly, C.; Jedidi, N.; Ouerghi, Z. Application of municipal solid waste compost reduces the negative effects of saline water in Hordeum maritimum L. Bioresour. Technol. 2008, 99, 7160-7167. [CrossRef]

14. Lakhdar, A.; Falleh, H.; Ouni, Y.; Oueslati, S.; Debez, A.; Ksouri, R.; Abdelly, C. Municipal solid waste compost application improves productivity, polyphenol content, and antioxidant capacity of Mesembryanthemum edule. J. Hazard. Mater. 2011, 191, 373-379. [CrossRef] [PubMed]

15. Trivedi, P.; Singh, K.; Pankaj, U.; Verma, S.K.; Verma, R.K.; Patra, D.D. Effect of organic amendments and microbial application on sodic soil properties and growth of an aromatic crop. Ecol. Eng. 2017, 102, 127-136. [CrossRef]

16. Ben Achiba, W.; Gabteni, N.; Lakhdar, A.; Du Laing, G.; Verloo, M.; Jedidi, N.; Gallali, T. Effects of 5-year application of municipal solid waste compost on the distribution and mobility of heavy metals in a Tunisian calcareous soil. Agric. Ecosyst. Environ. 2009, 130, 156-163. [CrossRef]

17. Roig, N.; Sierra, J.; Martí, E.; Nadal, M.; Schuhmacher, M.; Domingo, J.L. Long-term amendment of Spanish soils with sewage sludge: Effects on soil functioning. Agric. Ecosyst. Environ. 2012, 158, 41-48. [CrossRef]

18. Jordao, C.P.; Nascentes, C.C.; Cecon, P.R.; Fontes, R.L.; Pereira, J.L. Heavy metals availability in soil amended with composted urban solid wastes. Environ. Monit. Assess. 2006, 112, 309-326. [CrossRef] [PubMed]

19. Aydinalp, C.; Marinova, S. Distribution and forms of heavy metals in some agricultural soils. Pol. J. Environ. Stud. 2003, 12, 629-633.

20. Illera, V.; Walker, I.; Souza, P.; Cala, V. Short-term effects of biosolid and municipal solid waste application on heavy metals distribution in a degraded soil under a semi-arid environment. Sci. Total Environ. 2000, 255, 29-44. [CrossRef]

21. Pérez, D.V.; Alcantra, S.; Ribeiro, C.C.; Pereira, R.E.; Fontes, G.C.; Wasserman, M.A.; Venezuela, T.C.; Meneguelli, N.A.; Parradas, C.A.A. Composted municipal waste effects on chemical properties of Brazilian soil. Bioresour. Technol. 2007, 98, 525-533. [CrossRef]

22. Hueso-González, P.; Muñoz-Rojas, M.; Martínez-Murillo, J.F. The role of organic amendments in drylands restoration. Curr. Opin. Environ. Sci. Health 2017, 5, 1-6. [CrossRef]

23. Scotti, R.; Bonanomi, G.; Scelza, R.; Zoina, A.; Rao, M.A. Organic amendments as sustainable tool to recovery fertility in intensive agricultural systems. J. Soil Sci. Plant Nutr. 2015, 15, 333-352. [CrossRef]

24. Mtimet, A. Soils of Tunisia. In Soil Resources of Southern and Eastern Mediterranean Countries; Zdruli, P., Steduto, P., Lacirignola, C., Montaranella, L., Eds.; Options Méditerranéennes: Série B. Etudes et Recherches; CIHEAM: Bari, Italy, 2001; Volume 34, pp. 243-268.

25. Bouzaiane, O.; Cherif, H.; Saidi, N.; Jedidi, N.; Hassen, A. Effects of municipal solid waste compost application on the microbial biomass of cultivated and non-cultivated soil in a semi-arid zone. Waste Manag. Res. 2007, 25, 334-342. [CrossRef] [PubMed]

26. Mbarki, S.; Cerdà, A.; Zivcak, M.; Brestic, M.; Rabhi, M.; Mezni, M.; Abdelly, C.; Pascual, J.A. Alfalfa crops amended with MSW compost can compensate the effect of salty water irrigation depending on the soil texture. Process Saf. Environ. Prot. 2018, 115, 8-16. [CrossRef] 
27. Ben Achiba, W.; Gabteni, N.; Laing, G.D.; Verloo, M.; Jedidi, N.; Tahar, G. Heavy metal availability and uptake by wheat crops cultivated in Tunisian field plots amended during five years with municipal solid waste compost and farmyard manure. J. Res. Environ. Earth Sci. 2016, 4, 146-154.

28. Commission Regulation (EEC) No 202/91 of 28 January 1991 Amending Regulation (EEC) No 3885/90 Laying down Detailed Rules for the Application of the Import Arrangements Provided for in Council Regulation (EEC) No $3838 / 90$ for Frozen Meat of Bovine Animals Covered by CN Code 0202 and Products Covered by CN Code 02062991. Available online: http:/ / data.europa.eu/eli/reg/1991/202/oj (accessed on 5 April 2021).

29. Beretta, A.N.; Silbermann, A.V.; Paladino, L.; Torres, D.; Bassahun, D.; Musselli, R.; Garcia-Lamohte, A. Soil texture analyses by hydrometer: Modifications of the Bouyoucos method. Cien. Inv. Agrar. 2014, 41, 263-271. [CrossRef]

30. Walkley, A.; Black, I.A. An examination of the Degtjareff method for determining soil organic matter and a proposed modification of the chromic acid titration method. Soil Sci. 1934, 37, 29-38. [CrossRef]

31. Bremner, J.M. Chapter 37-Nitrogen-Total. In Methods of Soil Analysis. Part 3; Sparks, D.L., Page, A.L., Helmke, P.A., Loeppert, R.H., Soltanpour, P.N., Tabatabai, M.A., Johnston, C.T., Sumner, M.E., Eds.; Chemical Methods; SSSA Book Series no. 5; SSSA-ASA: Madison, WI, USA, 1996; pp. 1085-1122.

32. Murphy, J.; Riley, J.P. A modified single solution method for the determination of phosphate in natural waters. Anal. Chim. Acta 1962, 27, 31-36. [CrossRef]

33. Rauret, G. Extraction procedures for the determination of heavy metals in contaminated soil and sediment. Talanta 1998, 46, 449-455. [CrossRef]

34. Pauwels, J.; Van Ranst, E.; Verloo, M.; Mvondo Ze, A. Manuel de Laboratoire de Pédologie-Méthodes d'analyses de sols et de plantes. In Equipment et Gestion des Stocks de Verrerie et de Produits Chimiques; Publications Agricoles nr. 28, A.G.C.D.: Bruxelles, Belgium, 1992; p. 180.

35. Cantrell, I.C.; Linderman, R.G. 2001. Preinoculation of lettuce and onion with VA mycorrhizal fungi reduces deleterious effects of soil salinity. Plant Soil 2001, 233, 269-281. [CrossRef]

36. Singh, R.P.; Agrawal, M. Potential benefits and risks of land application of sewage sludge. Waste Manag. 2008, 28, 347-358. [CrossRef]

37. Rattan, R.K.; Datt, S.P.; Chhonkar, P.K.; Suribabu, K.; Singh, A.K. Long-term impact of irrigation with sewage effluents on heavy metal content in soils, crops and groundwater-A case study. Agric. Ecosyst. Environ. 2005, 67, 824-837. [CrossRef]

38. Alvarenga, P.; Palma, P.; Mourinha, C.; Farto, M.; Dores, J.; Patanita, M.; Cunha-Queda, C.; Natal-da-Luz, T.; Renaud, M.; Sousa, J.P. Recycling organic wastes to agricultural land as a way to improve its quality: A field study to evaluate benefits and risks. Waste Manag. 2017, 61, 582-592. [CrossRef]

39. Yüksel, O.; Kavdır, Y. Improvement of Soil Quality Parameters by Municipal Solid Waste Compost Application in Clay-Loam Soil. Turk. J. Agric.-Food Sci. Technol. 2020, 8, 603. [CrossRef]

40. Nicolardot, B.; Recous, S.; Mary, B. Simulation of C and N mineralization during crop residue decomposition: A simple dynamic model based on the C: $\mathrm{N}$ ratio of the residues. Plant Soil 2001, 228, 83-103. [CrossRef]

41. Gutser, R.; Ebertseder, T.; Weber, A.; Schraml, M.; Schmidhalter, U. Short-term and residual availability of nitrogen after long-term application of organic amendments on arable land. J. Plant Nutr. Soil Sci. 2005, 168, 439-446. [CrossRef]

42. Norton, J.; Ouyang, Y. Controls and adaptive management of nitrification in agricultural soils. Front. Microbiol. 2019, 10, 1929-1931. [CrossRef] [PubMed]

43. Demelash, N.; Bayu, W.; Tesfaye, S.; Ziadat, F.; Sommer, R. Current and residual effects of compost and inorganic fertilizer on wheat and soil chemical properties. Nutr. Cycl. Agroecosyst. 2014, 100, 357-367. [CrossRef]

44. Meena, M.D.; Joshi, P.K.; Jat, H.S.; Chinchmalatpure, A.R.; Narjary, B.; Sheoran, P.; Sharma, D.K. Changes in biological and chemical properties of saline soil amended with municipal solid waste compost and chemical fertilizers in a mustard-pearl millet cropping system. Catena 2016, 140,1-8. [CrossRef]

45. Hechmi, S.; Hamdi, H.; Mokni-Tlili, S.; Ghorbel, M.; Khelil, M.N.; Zoghlami, I.R.; Benzarti, S.; Jellali, S.; Hassen, A.; Jedidi, N. Impact of urban sewage sludge on soil physico-chemical properties and phytotoxicity as influenced by soil texture and reuse conditions. J. Environ. Qual. 2020, 49, 973-986. [CrossRef]

46. Loveland, P.; Webb, J. Is there a critical level of organic matter in the agricultural soils of temperate regions: A review. Soil Till. Res. 2003, 70, 1-18. [CrossRef]

47. Alvarenga, P.; Farto, M.; Mourinha, C.; Palma, P. Beneficial Use of Dewatered and Composted Sewage Sludge as Soil Amendments: Behaviour of Metals in Soils and Their Uptake by Plants. Waste Biomass. Valor. 2016, 7, 1189-1201. [CrossRef]

48. Domínguez, M.; Paradelo Núñez, R.; Piñeiro, J.; Barral, M.T. Physicochemical and biochemical properties of an acid soil under potato culture amended with municipal solid waste compost. Int. J. Recycl. Org. Waste Agric. 2019, 8, 171-178. [CrossRef]

49. Masmoudi, S.; Magdich, S.; Rigane, H.; Medhioub, K.; Rebai, A.; Ammar, E. Effects of Compost and Manure Application Rate on the Soil Physico-Chemical Layers Properties and Plant Productivity. Waste Biomass. Valori. 2018, 11, 1883-1894. [CrossRef]

50. NFU 44-051. French Regulation Established by AFNOR for Organic Amendments.; AFNOR: Paris, France, 2006. (In French)

51. Kidd, P.S.; Domínguez-Rodríguez, M.J.; Díez, J.; Monterroso, C. Bioavailability and plant accumulation of heavy metals and phosphorus in agricultural soils amended by long-term application of sewage sludge. Chemosphere 2007, 66, 1458-1467. [CrossRef] [PubMed] 
52. Lasheen, M.R.; Ammar, N.S. Assessment of metals speciation in sewage sludge and stabilized sludge from different Wastewater Treatment Plants, Greater Cairo, Egypt. J. Hazard. Mater. 2009, 164, 740-749. [CrossRef]

53. Gadepalle, V.P.; Ouki, S.K.; Van Herwijnen, R.; Hutchings, T. Immobilization of heavy metals in soil using natural and waste materials for vegetation establishment on contaminated sites. Soil Sediment Contam. 2007, 16, 233-251. [CrossRef]

54. Parat, C.; Chaussod, R.; Leveque, J.; Andreux, F. Long-term effects of metal containing farmyard manure and sewage sludge on soil organic matter in a fluvisol. Soil Biol. Biochem. 2005, 37, 673-679. [CrossRef]

55. Collivignarelli, M.C.; Abbà, A.; Frattarola, A.; Carnevale Miino, M.; Padovani, S.; Katsoyiannis, I.; Torretta, V. Legislation for the Reuse of Biosolids on Agricultural Land in Europe: Overview. Sustainability 2019, 11, 6015. [CrossRef]

56. Mbarki, S.; Skalicky, M.; Talbi, O.; Chakraborty, A.; Hnilicka, F.; Hejnak, V.; Zivcak, M.; Brestic, M.; Cerda, A.; Abdelly, C. Performance of Medicago sativa Grown in Clay Soil Favored by Compost or Farmyard Manure to Mitigate Salt Stress. Agronomy 2020, 10, 94. [CrossRef]

57. Hammad, H.M.; Khaliq, A.; Abbas, F.; Farhad, W.; Fahad, S.; Aslam, M.; Shah, G.M.; Nasim, W.; Mubeen, M.; Bakhat, H.F. Comparative Effects of Organic and Inorganic Fertilizers on Soil Organic Carbon and Wheat Productivity under Arid Region. Comm. Soil Sci. Plant Anal. 2020, 10, 1406-1422. [CrossRef]

58. Tejada, M.; Gonzalez, J.L. Effects of the application of a compost originating from crushed cotton gin residues on wheat yield under dryland conditions. Eur. J. Agron. 2003, 19, 357-368. [CrossRef]

59. Hussein, M.S.; El-Sherbeny, S.E.; Khalil, M.Y.; Naguib, N.Y.; Aly, S.M. Growth characters and chemical constituents of Dracocephalum moldavica L. plants in relation to compost fertilizer and planting distance. Sci. Horticult. 2006, 108, 322-331. [CrossRef]

60. Malik, M.A.; Khan, K.S.; Marshchner, P.; Ali, S. Organic amendments differ in their effect on microbial biomass and activity and on P pools in alkaline soils. Biol. Fertil. Soils 2013, 49, 415-425. [CrossRef]

61. Escobedo-Monge, M.A.; Aparicio, S.; Escobedo-Monge, M.F.; Marugán-Miguelsanz, J.M. Long-Term Effects of the Application of Urban Waste Compost and Other Organic Amendments on Solanum tuberosum L. Agronomy 2020, 10, 1575. [CrossRef]

62. Corrêa, R.S.; White, R.E.; Weatherley, A.J. Effect of compost treatment of sewage sludge on nitrogen behavior in two soils. Waste Manag. 2006, 26, 614-619. [CrossRef]

63. Bhattacharyya, P.; Chakrabarti, K.; Chakraborty, A.; Nayak, D.C.; Tripathy, S.; Powell, M.A. Municipal waste compost as an alternative to cattle manure for supplying potassium to lowland rice. Chemosphere 2007, 66, 1789-1793. [CrossRef] [PubMed]

64. Mohamed, M.F.; Thalooth, A.T.; Elewa, T.A.; Ahmed, A.G. Yield and nutrient status of wheat plants (Triticum aestivum L.) as affected by sludge, compost, and biofertilizers under newly reclaimed soil. Bull. Natl. Res. Cent. 2019, 43, 31-36. [CrossRef]

65. Khan, K.S.; Joergensen, R.G. Compost and phosphorus amendments for stimulating microorganisms and growth of ryegrass in a Ferralsol and a Luvisol. J. Plant Nutr. Soil Sci. 2012, 175, 108-114. [CrossRef]

66. Warman, P.R.; Murphy, C.; Burnham, J.; Eaton, L. Soil and plant response to MSW compost applications on lowbush blueberry fields in 2000 and 2001. Small Fruits Rev. 2004, 3, 19-31. [CrossRef]

67. Thomas, C.L.; Acquah, G.E.; Whitmore, A.P.; McGrath, S.P.; Haefele, S.M. The effect of different organic fertilizers on yield and soil and crop nutrient concentrations. Agronomy 2019, 9, 776. [CrossRef]

68. Karthika, K.S.; Parama, V.R.R.; Subbarayappa, C.T.; Hemalatha, B.; Vidya, C.S. Residual effect of enzyme industrial wastemunicipal solid waste composts application on growth, yield, content and uptake of nutrients by cowpea. Int. J. Curr. Microbiol. App. Sci. 2018, 7, 1386-1395. [CrossRef]

69. Shah, G.M.; Tufail, N.; Bakhat, H.F.; Ahmad, I.; Shahid, M.; Hammad, H.M.; Nasim, W.; Waqar, A.; Rizwan, M.; Dong, R. Composting of municipal solid waste by different methods improved the growth of vegetables and reduced the health risks of cadmium and lead. Environ. Sci. Pollut. Res. 2019, 26, 5463-5474. [CrossRef] [PubMed]

70. Kabata-Pendias, A.; Pendias, H. Trace Elements in Soils and Plants, 3rd ed.; CRC Press: Boca Raton, FL, USA, 2001. 